\title{
Conceptual and numerical models of a tectonically-controlled geothermal system: a case study of the Euganean Geothermal System, Northern Italy
}

\author{
Marco Pola*, Paolo Fabbri, Leonardo Piccinini, Dario Zampieri \\ Dipartimento di Geoscienze, Università degli Studi di Padova, Padova, Italy
}

Received: January 28, 2015; accepted: January 28, 2015

The Euganean Geothermal Field (EGF) is the most important thermal field in northern Italy. It is located in the alluvial plain of the Veneto Region where approximately $17 * 10^{6} \mathrm{~m}^{3}$ of thermal water with temperatures of $60-86{ }^{\circ} \mathrm{C}$ are exploited annually. A regional-scale conceptual model of the Euganean Geothermal System is proposed in this paper using the available hydrogeologic, geochemical and structural data for both the EGF and central Veneto. The thermal water is of meteoric origin and infiltrates approximately $80 \mathrm{~km}$ to the north of the EGF in the Veneto Prealps. The water flows to the south in a Mesozoic limestone and dolomite reservoir reaching a depth of approximately 3,000 $\mathrm{m}$ and a temperature of approximately $100{ }^{\circ} \mathrm{C}$ due to the normal geothermal gradient. The regional Schio-Vicenza fault system and its highly permeable damage zone act as a preferential path for fluid migration in the subsurface. In the EGF area, a geologic structure formed by the interaction of different segments of the fault system increases the local fracturing and the permeability favoring the upwelling of the thermal waters. Numerical simulations are performed to validate the proposed conceptual model using a finite difference code that simulates thermal energy transport in hydrothermal systems. A specific configuration of thermal conductivity and permeability for the formations involved in the thermal system is obtained after calibration of these parameters. This set of parameters is verified in a long-term simulation $(55,100$ years) obtaining a $60-70{ }^{\circ} \mathrm{C}$ plume in the EGF area. The modeled temperatures approach the measured temperatures of $60-86^{\circ} \mathrm{C}$, demonstrating that this conceptual model can be realistically simulated.

Keywords: Euganean Geothermal System, strike-slip fault, fault damage zone, numerical modeling

\footnotetext{
* Corresponding author: Via G. Gradenigo 6, 35131 Padova, Italy;

E-mail: marco.pola@unipd.it
} 


\section{Introduction}

Thermal waters are widely used for therapeutic purposes and recreational tourism, and thermal spas and resorts can be found in most geothermal areas, representing a significant economic resource in many countries. The Euganean Geothermal Field (EGF) is one of the most important thermal fields in northern Italy (Fig. 1A). The EGF is located on a strip of approximately $25 \mathrm{~km}^{2}$ to the southwest of Padova and to the east of the Euganei Hills (Veneto Region; Figs 1A and 1B) and has been well known since the Roman period. The thermal field comprises the spa towns of Abano Terme, Montegrotto Terme, Battaglia Terme and Galzignano Terme (Fig. 1C), where more than 400 wells have been drilled since the 1960s due to increasing demand for the thermal waters. Approximately 250 wells are presently active and exploit $17 * 10^{6}$

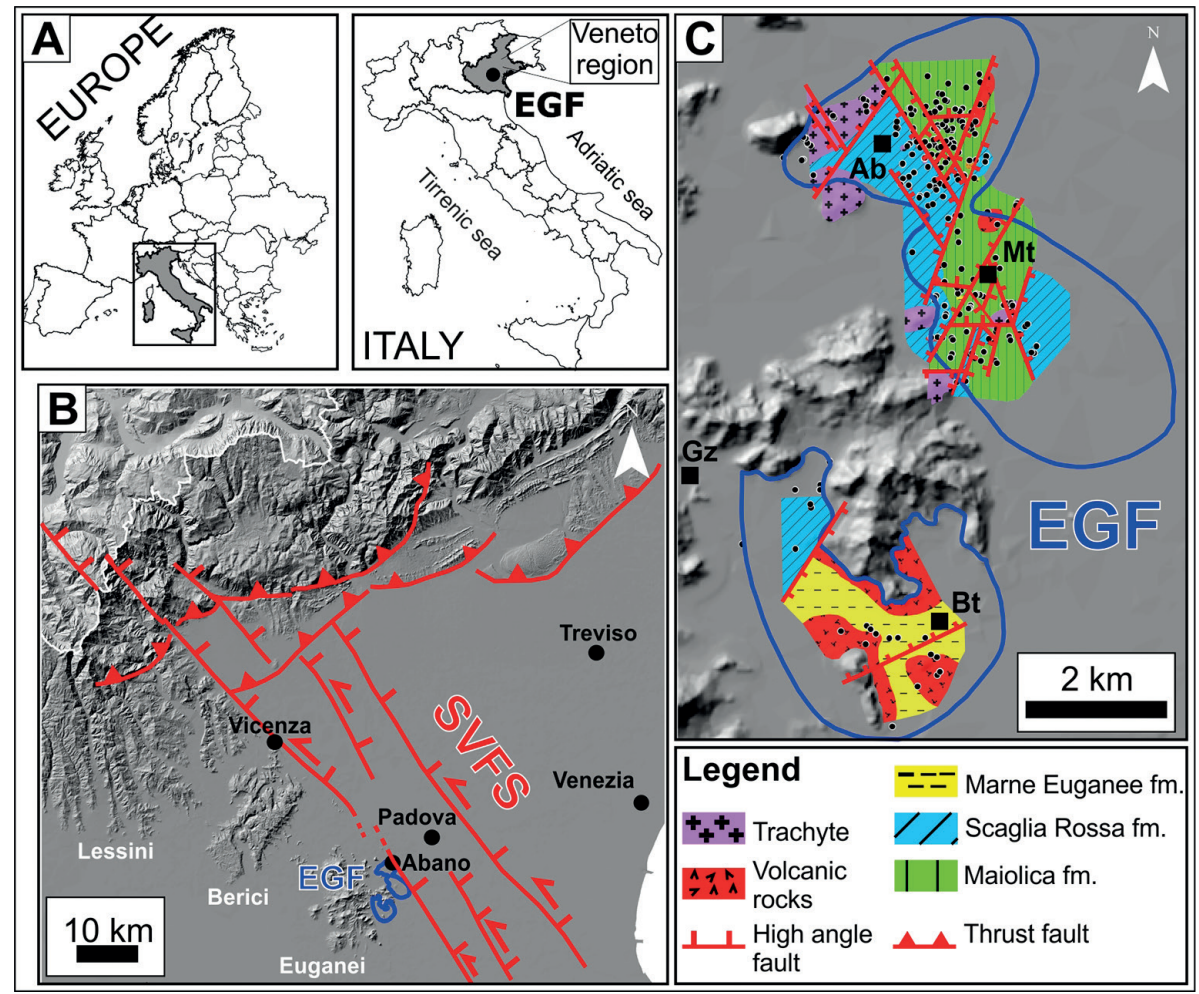

Fig. 1

(A) Location of the Euganean Geothermal Field (EGF) within the central part of the Veneto Region (NE Italy). (B) Structural sketch of central Veneto with the NW-SE-trending Schio-Vicenza fault system (SVFS). (C) Schematic geologic map of the EGF subsurface reconstructed using the stratigraphic logs of the thermal wells (black dots). The bedrock is divided into a mosaic of blocks by a network of high-angle faults. The main towns of the EGF are shown (Ab: Abano Terme; Mt: Montegrotto Terme; Bt: Battaglia Terme; Gz: Galzignano Terme). 
$\mathrm{m}^{3} / \mathrm{y}$ of thermal water. The water is primarily used for health and spa purposes and secondarily to warm hotels and for tropical flower-growing.

Piccoli et al. (1973), proposing a first conceptual model, suggested that the EGF is the outflow area of a regional-scale hydrothermal system. The aim of this research is to update the model of the Euganean Geothermal System using the knowledge developed over the last 40 years of study. Numerical simulations are performed to validate the proposed conceptual model and to verify whether the Euganean Geothermal system can be realistically reproduced using a code for groundwater flow and heat transport.

\section{Geologic and hydrogeologic settings}

\section{Geologic setting}

The geologic setting of the EGF (Fig. 1C) has been reconstructed since the 1990s using the stratigraphic logs of drilled wells, some of which reach a depth of 1,000 m (Antonelli et al. 1993, 1994). The thickness of the Quaternary alluvial cover ranges from a few meters (i.e. Battaglia Terme and Galzignano Terme and locally at Montegrotto Terme) to approximately $200 \mathrm{~m}$ (Abano Terme). The typical stratigraphic sequence found beneath the alluvial cover is composed of: i) Triassic to Eocene limestone, dolostone and mudstone (i.e. Marne Euganee Formation, Early Eocene-Early Oligocene; Scaglia Rossa Formation, Late Cretaceous-Early Eocene; Maiolica Formation, Late Jurassic-Late Cretaceous; Rosso Ammonitico Formation, Late Jurassic; Calcari Grigi Formation, Early-Middle Jurassic; Dolomia Principale Formation, Late Triassic); and ii) Late Eocene-Early Oligocene volcanic rocks (i.e. trachyte, rhyolite, basalt and latite) that crop out in the nearby Euganei Hills and can be ascribed to the Paleogene magmatism of northeastern Italy. The units beneath are made of Permian-Triassic limestone, dolostone, sandstone and evaporitic rocks that lie above the pre-Permian crystalline basement of the Southern Alps. The subsurface of the EGF is fragmented into a mosaic of blocks by a network of high-angle faults (main directions: NNE-SSW, E-W, NNW-SSE; Fig. 1C). A similar pattern of open fractures (main directions: NNE-SSW, ESE-WNW, NW-SE) deforms a travertine mound (Montirone Hill) located in Abano Terme (Pola et al. 2011, 2014a).

From a regional point of view the EGF is located along the Schio-Vicenza fault system (SVFS), which extends for approximately $120 \mathrm{~km}$ in the Veneto alluvial plain from the foot of the Prealps to the Po delta (Pola et al. 2014b; partially shown in Fig. 1B). This system is composed of NW-SE to NNW-SSE trending, NE-dipping, high-angle faults buried beneath the Quaternary alluvial cover of the Veneto plain, and it bounds the northeastern part of the Adria Plate indenter to the west (Burrato et al. 2008; Pola et al. 2014b). The SVFS developed as a system of high-angle normal faults during Mesozoic and Paleogene, when it accommodated the extension affecting the passive margin of the Adria plate (Zampieri 1995; Masetti et al. 2012). Subsequently, it 
was reactivated during the Neogene flexural cycles bending the Veneto plain (Fantoni et al. 2002) and was mainly active during the last Pliocene-Quaternary flexural cycle, accommodating: i) the flexuring towards the south with a vertical scissor movement (Pola et al. 2014b); and ii) the northward movement of the Adria Plate indenter (e.g. D'Agostino et al. 2005) with sinistral strike-slip or transtensional kinematics.

A linkage between the SVFS and the Euganean Geothermal System may be supposed (Zampieri et al. 2009, 2010; Pola et al. 2013) because faults are recognized as the most efficient path for fluid migration in the subsurface (e.g. Curewitz and Karson 1997; Perello et al. 2001; Baietto et al. 2008; Faulkner et al. 2010). Curewitz and Karson (1997), in a global study on thermal springs, stated that $78 \%$ of hot springs are located near faults, with the most common settings being those of fault tip-lines (33\%) and interaction areas between faults (25\%). In particular, a fault zone (Faulkner et al. 2010 ) is generally composed of: i) the fault core made of gouges, cataclasites and/or ultracataclasites; ii) the damage zone formed by fractures over a wide range of length scales and subsidiary faults; and iii) the protolith representing the undeformed rock. The density of fractures increases from the protolith to the fault core, whereas the permeability reaches its maximum value in the damage zone due to the high density of interconnected fractures.

\section{Hydrogeologic setting}

The Euganean thermal waters (Norton and Panichi 1978; Gherardi et al. 2000; Fabbri, 2001; Fabbri and Trevisani 2005) are characterized by: i) temperatures from $60{ }^{\circ} \mathrm{C}$ to $86^{\circ} \mathrm{C}$; ii) basic $\mathrm{pH}$ from 6.3 to 7.4 , which is independent of temperature; iii) high values of total dissolved solids from 3.5 to $6 \mathrm{~g} / \mathrm{L}$ with the principal constituents being primarily $\mathrm{Cl}^{-}$and $\mathrm{Na}^{+}$(70 wt. \%) and secondarily $\mathrm{SO}_{4}^{2-}, \mathrm{Ca}^{2+}, \mathrm{Mg}^{2+}, \mathrm{HCO}_{3}^{-}$and $\mathrm{SiO}_{2}$; iv) stable isotope compositions that are more negative than the local meteoric water (Euganean thermal water: $\delta^{18} \mathrm{O}$ from $-11.5 \%$ V-SMOW to $-10.1 \%$ o-SMOW and $\delta \mathrm{D}$ from $-84.8 \% \mathrm{~V}-\mathrm{SMOW}$ to $-71.5 \% \mathrm{~V}-\mathrm{SMOW}$; local meteoric water: $\delta^{18} \mathrm{O}$ of approximately $-8.5 \% \mathrm{~V}$-SMOW and $\delta \mathrm{D}$ of approximately $-55 \pm 5 \% \mathrm{~V}$-SMOW); and v) absent or very low ${ }^{3} \mathrm{H}$ content.

The stable isotope data of the Euganean fluids reveal a common meteoric origin and suggest an infiltration area located at approximately $1,500 \mathrm{~m}$ a.s.l. (Norton and Panichi 1978; Gherardi et al. 2000). The parent meteoric water acquires its high salinity and chlorinity through prolonged leaching reactions with the sedimentary formations of the reservoir. In particular, the quite constant $\mathrm{Ca} / \mathrm{SO}_{4}$ ratio $(0.46 \pm 0.4)$, which is in agreement with the gypsum-anhydrite reference value $(\sim 0.42)$, suggests a circulation of the thermal water through evaporitic formations (Gherardi et al. 2000). The reservoir equilibrium temperatures are estimated using the $\mathrm{SiO}_{2}$ and $\mathrm{K} / \mathrm{Mg}$ geothermometers, which indicate an equilibration temperature from 80 to $100{ }^{\circ} \mathrm{C}$ (Gherardi et al. 2000). The ${ }^{3} \mathrm{H}$ and ${ }^{14} \mathrm{C}$ measurements suggest a residence time greater than 60 years and probably in the range of a few thousand years (Sartori et al. 1997; Gherardi et al. 2000; Boaretto et al. 2003). 
The Euganean thermal waters are mainly exploited from highly fractured horizons located at a depth between $300 \mathrm{~m}$ and $500 \mathrm{~m}$ within the Maiolica Formation. The transmissivity of the aquifer was estimated between $13 \mathrm{~m}^{2} / \mathrm{d}$ and $500 \mathrm{~m}^{2} / \mathrm{d}$ (Antonelli and Fabbri 1988; Fabbri and Matteotti 1989, 1992; Fabbri 1997). The potentiometric level of this aquifer is a few meters below ground level, and its annual trend shows anthropic seasonal variations related to the touristic seasons (Fabbri and Soccorso 2007; Pola et al. 2015). As a matter of fact, a decrease of the level occurs during spring and autumn, when there is a higher exploitation of thermal waters related to the high rate of incoming tourists, whereas an increase takes place during winter and summer, when the demand for thermal water is lower. Other secondary thermal aquifers are found at different depths: i) the sandy layers of the Quaternary alluvial cover host thermal waters with slightly lower temperatures (i.e. $48{ }^{\circ} \mathrm{C}$ at $56 \mathrm{~m}$ below ground level and $79{ }^{\circ} \mathrm{C}$ at $136 \mathrm{~m}$ below ground level) that were exploited in the recent past but are presently not used; and ii) the fractured layers, located at approximately 800-1,000 m depth in the Calcari Grigi Formation and in upper part of the Dolomia Principale Formation, form a deeper thermal aquifer bearing thermal waters with higher temperatures (approximately $80{ }^{\circ} \mathrm{C}$ ) and a potentiometric level above ground level due to the still-moderate exploitation. All aquifers (i.e. sandy aquifers and rocky aquifers at different depths) exhibit similar seasonal variations of the potentiometric level, suggesting that they are hydraulically connected.

The first conceptual model of the Euganean Geothermal System was proposed by Piccoli et al. (1973). It locates the thermal system to the west of the SVFS, and the parent meteoric water flows through a Mesozoic carbonate aquifer below the Lessini and Berici Mountains up to the EGF. This model can be considered out of date due to the presently available data on the geologic setting of Veneto (Antonelli et al. 1990; Pola et al. 2014b) and the geologic and hydrogeologic setting of the EGF (Antonelli et al. 1993; Fabbri 2001; Fabbri and Trevisani 2005; Fabbri and Soccorso 2007; Zampieri et al. 2009; Pola et al. 2013, 2014a, 2015).

\section{Methods}

The geologic setting of the subsurface to the east of the central Veneto reliefs (i.e. the Lessini and Berici Mountains and Euganei Hills) and the architecture of the Schio-Vicenza fault system (SVFS) have been recently described using a collection of seismic data (Fig. 1B; Pola et al. 2014b). In particular, the northern and southern parts of the fault system are well constrained through seismic sections, whereas the central area close to Padova and the EGF suffers from a lack of seismic data due to the proximity of the relief (Fig. 2A). The new gravimetric map of Italy (Ferri et al. 2005) is used to fill the gap in the architecture of the fault system (Fig. 2A). The map (with a pixel size of $1 \mathrm{~km}^{2}$ ) was obtained through the interpolation of onshore and offshore gravimetric data, and it constitutes a useful tool in clarifying the geometry of buried regional structural elements (Ferri et al. 2005). The digital elevation model of the gravimetric map is processed through the SLOPE function in the ESRI ArcGIS 
package. This process allows identifying areas characterized by a steeper gradient in the Bouguer anomaly, which can be interpreted to be the result of faulting.
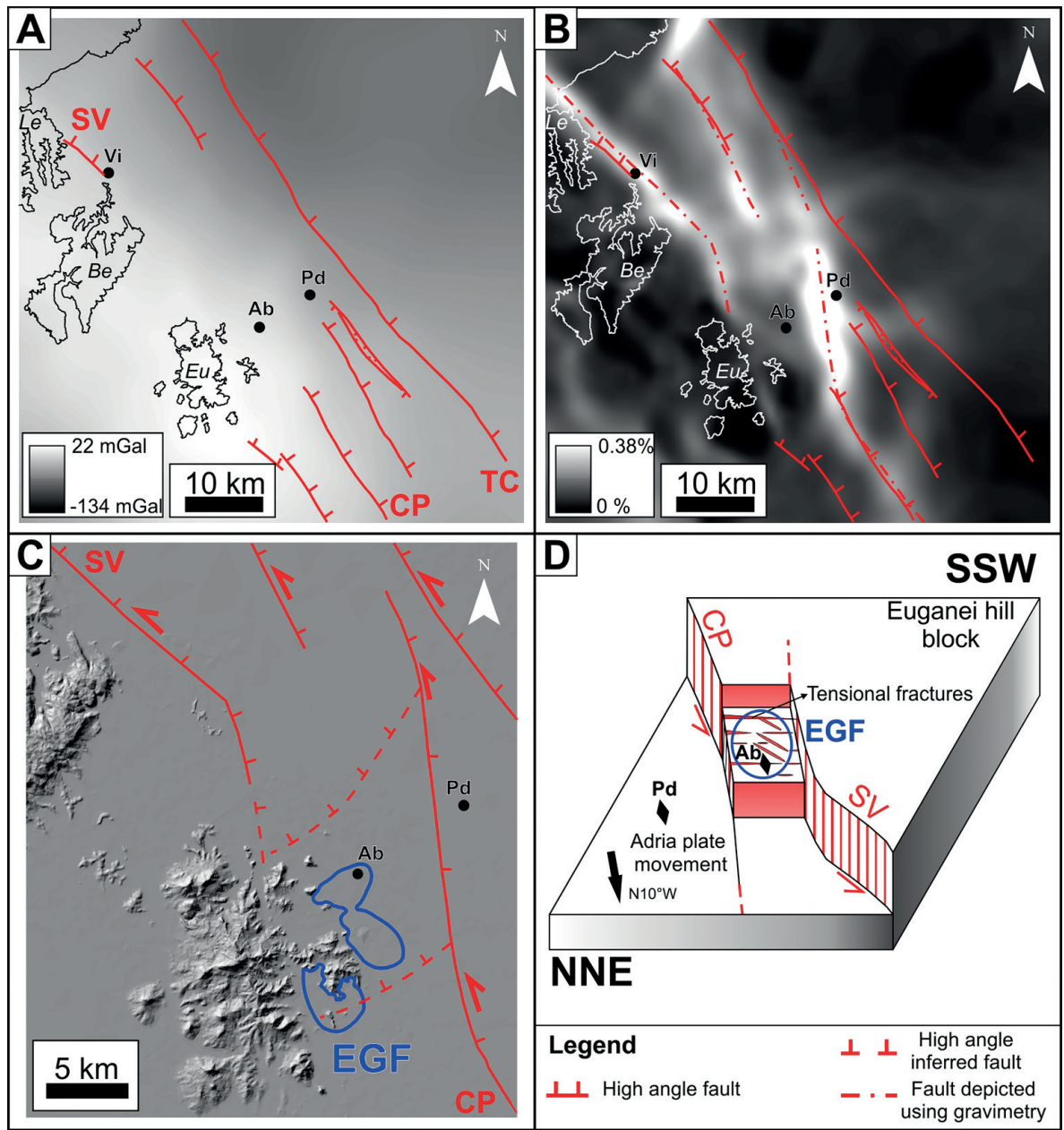

Fig. 2

(A) Gravimetric map of central Veneto (Ferri et al. 2005) with the architecture of the SVFS obtained from seismic data (main faults: Conselve-Pomposa, CP; Travettore-Codevigo, TC; Schio-Vicenza, SV; Pola et al. 2014b). A gap in this interpretation, due to a lack of data in the seismic database, is shown close to the relief (Le: Lessini Mountains; Be: Berici Mountains; Eu: Euganei Hills) between Vicenza (Vi), Padova (Pd) and Abano Terme (Ab). (B) Slope of the gravimetric map showing areas with a steeper Bouguer anomaly gradient (white area), which are interpreted as fault-related (dotted lines). A good correspondence between the architectures obtained through seismic and gravimetric data is observed. (C) Updated architecture of the SVFS in the area near the EGF. The Schio-Vicenza Fault partially overlaps the Conselve-Pomposa Fault, forming an interaction zone between the faults that is interpreted to be a relay ramp. (D) Schematic model of the relay ramp (not to scale). Tensional open fractures develop within the relay ramp, enhancing the upwelling of the thermal water in the EGF. 
The structural data on the central Veneto (Antonelli et al. 1990; Pola et al. 2014b), the chemical data on the Euganean thermal waters (Norton and Panichi 1978; Sartori et al. 1997; Gherardi et al. 2000; Boaretto et al. 2003) and the stratigraphic, hydrogeologic and structural data on the EGF (Antonelli et al. 1993; Fabbri 2001; Fabbri and Trevisani 2005; Pola et al. 2014a) are used to propose a conceptual model of the Euganean Geothermal System.

A numerical model is performed in order to verify the proposed conceptual model. This is the first numerical model developed for the Euganean Geothermal System, and it is performed using the finite difference code HYDROTHERM version 3 (Kipp et al. 2008). This code simulates thermal energy transport in two or three-dimensional, multi-phase (liquid and steam), groundwater, single fluid component (pure water) flow systems, and it has been used in different hydrothermal settings (e.g. Ingebritsen and Rojstaczer 1996; Hurwitz et al. 2003). The two partial differential equations solved by the code are the water-component flow equation and the thermal-energy transport equation. These equations are coupled through the dependence of advective heat transport on the interstitial fluid velocity field and the dependence of fluid density, viscosity, and saturation on pressure. The governing equations are solved numerically through finite-difference approximation.

\section{Results and Discussions}

\section{Structural constraints on the Euganean thermal water circulation}

The analysis of the gravimetric map of central Veneto (Fig. 2A) reveals a decrease in the Bouguer anomaly value moving east away from the relief. Although this variation appears to be smooth, the slope map displays areas that are affected by a sharp gradient (white areas in Fig. 2B), which is interpreted as a fault-related increase in the depth of the subsurface. The highlighted NW-SE-trending fault segments extend approximately 70 $\mathrm{km}$ from the foot of the Lessini Mountains to the south of the Euganei Hills. In addition, four segments approach the faults depicted in the seismic data (Pola et al. 2014b; Fig. 2B), constraining the interpretation obtained from gravimetric data. The architecture of the fault system can be rearranged for the area without seismic data (Fig. 2C): i) the NW-SE-trending Schio-Vicenza Fault is extended along the eastern border of the Lessini and Berici Mountains; and ii) the Conselve-Pomposa Fault extends to the north of Padova with a main N-S trend. The northern part of the Conselve-Pomposa Fault and the southern part of the Schio-Vicenza Fault overlap (Fig. 2C) and may form an interaction zone between the faults of the SVFS. The interaction zone evolved in accordance with the kinematic evolution of the fault system (Pola et al. 2014b); therefore it probably originated as a relay ramp during Mesozoic to Paleogene extension, when the SVFS was a system of normal faults. Subsequently, the SVFS was reactivated with sinistral strikeslip or transtensional kinematics during the Neogene, and the ramp was segmented by two faults that connected the bounding faults, forming a breached relay ramp (Fig. 2D). 
Relay ramps (e.g. Peacock and Sanderson 1994; Trudgill and Cartwright 1994; Peacock and Sanderson 1995; Long and Imber 2011), and in general interaction zones of faults, are potential sites of hydrothermal fluid flow because they are characterized by high stress, which increases the local fracturing and permeability (Curewitz and Karson 1997; Ferrill and Morris 2001; Rotevatn et al. 2007). The EGF coincides with the breached relay ramp of the SVFS (Figs 2C and 2D). Given the sinistral strikeslip kinematics superimposed on the bounding faults, the relay ramp accommodates along-strike local extension, producing a local fracture mesh that increases both the local permeability and the fluid migration to the surface. The network of fractures that deforms the Montirone travertine hill in Abano Terme (main directions: NNESSW, ESE-WNW, and NW-SE) constitutes the surface manifestation of the fractures deforming the bedrock, as also suggested by the calculation of the theoretical fracture mesh that develops within the interaction zone (Pola et al. 2014a).

\section{Euganean Geothermal System conceptual model}

The interpretation of the Schio-Vicenza fault system and all the data on the EGF are used to propose a conceptual model of the Euganean Geothermal System (Fig. 3A) and to construct a standard cross-section (Fig. 3B).

The relay ramp increases the fracturing of the bedrock and the local permeability in the Euganean Geothermal Field (EGF). The fracture mesh is similar to the fracture network of the Montirone travertine mound (Pola et al. 2014a). In particular, the ESE-WNW-trending $50 \mathrm{~cm}$-wide tensional fissures permit the rapid upwelling of the thermal water from the deeper part of the reservoir and their subsequent horizontal flux. As a matter of fact, the direction of this set of fractures parallels the direction of the anisotropy $\left(\mathrm{N} 110^{\circ} \mathrm{E}\right)$ shown in the variogram map of the thermal aquifer transmissivity (Fabbri 1997). The anisotropy is evidence of similar values of transmissivity along this direction, suggesting a preferential flow path for fluids through open fractures in the subsurface. In addition the water flux is increased by the discontinuities in the subsurface like magmatic bodies, which crop out in the nearby Euganei Hills, and karstic conduits, which are locally found during drilling (unpublished data). A quick ascent is constrained by the highest temperatures of the waters measured in the EGF wells (greater than $80{ }^{\circ} \mathrm{C}$ in some wells and up to $95^{\circ} \mathrm{C}$ in vertical thermal logs; unpublished data), which approach the temperatures of the deep reservoir calculated by the geothermometers $\left(80-100{ }^{\circ} \mathrm{C}\right.$; Gherardi et al. 2000). The thermal waters rise through the fracture mesh and subsequently spread horizontally in fractured layers located in the Dolomia Principale, Calcari Grigi and Maiolica Formations. Presently, the most exploited aquifer is located within the Maiolica Formation at a depth of $300 \mathrm{~m}$ to $500 \mathrm{~m}$. The lateral spreading of the thermal waters is suggested by: i) the temperatures of the water exploited from the 300-500 $m$ deep aquifer by similarly deep wells decrease moving away from the areas where the parent water emerges directly from the deep reservoir (the parent water shows the highest temperature values and the lowest $\delta^{18} \mathrm{O}$; Gherardi et al. 2000); and ii) in 


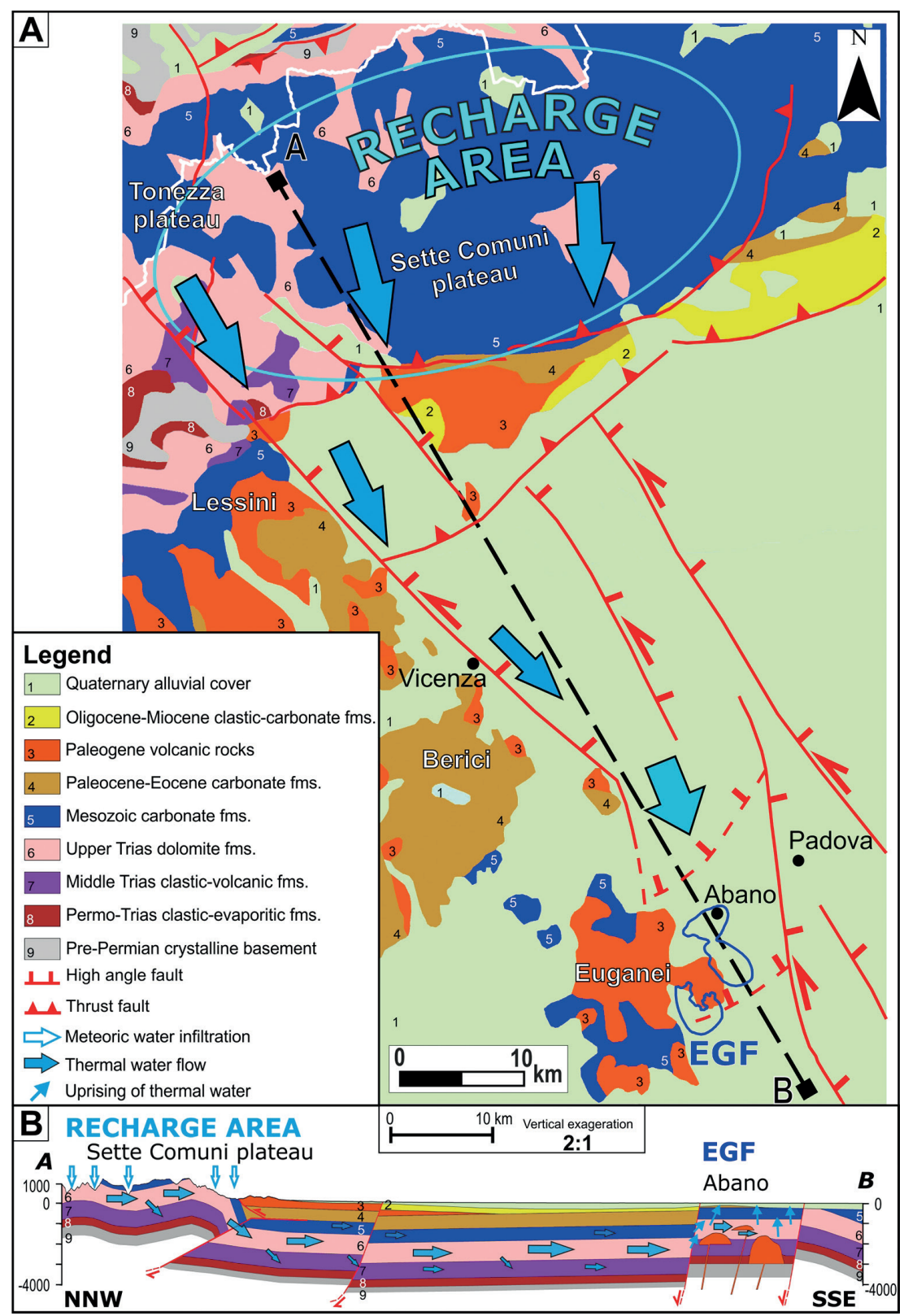

Fig. 3

(A and B) Conceptual model of the Euganean Geothermal System proposed in this paper. See the text for an extended explanation. The dotted line represents the track of the cross-section of the model (B). The magmatic bodies in the subsurface of the EGF are schematically drawn with the aim of showing their occurrence and their role in the flow of thermal waters. 
the distal zones characterized by "lower temperatures", waters exploited from wells deeper than $500 \mathrm{~m}$ (i.e. the maximum depth of the most exploited reservoir) have higher temperatures. Locally, the thermal waters rise toward the surface developing discontinuous thermal aquifers in the sandy layers of the Quaternary alluvial cover (i.e. $48^{\circ} \mathrm{C}$ at $56 \mathrm{~m}$ below ground level and $79^{\circ} \mathrm{C}$ at $136 \mathrm{~m}$ below ground level). All the aquifers (i.e. the sandy and rocky aquifers at different depths) are hydraulically connected, as suggested by the observed similar seasonal variations in the potentiometric level (i.e. high levels in summer and winter, low levels in spring and autumn; Fabbri and Soccorso 2007; Pola et al. 2015).

Moving northward from the EGF, the Schio-Vicenza Fault acts as a conduit for the thermal water flux in the subsurface (Fig. 3A) because of the higher permeability of the fault damage zone (Faulkner et al. 2010). In the middle part of the thermal system, the water flows through the Mesozoic limestone and dolomite formations that also constitute the thermal aquifer in the EGF. These formations are located at a depth between 2,000 and 3,000 $\mathrm{m}$ (Fig. 3B), and the fluids warm up to approximately 100 ${ }^{\circ} \mathrm{C}$ via: i) the normal geothermal gradient $\left(30^{\circ} \mathrm{C} / \mathrm{km}\right)$; and ii) exothermic reactions between anhydrite and the parent meteoric water (Gherardi et al. 2000). Additionally, a vertical water flux between the Mesozoic limestone and dolomite formations and the underlying Permian-Triassic sandy-evaporitic formations occurs as well, as suggested by the $\mathrm{Ca} / \mathrm{SO}_{4}$ ratio of the thermal water $(0.46 \pm 0.4)$, which is in agreement with the gypsum-anhydrite reference value $(\sim 0.42)$. The interaction between deeply infiltrated meteoric water and the gypsum, dolomite and calcite of the reservoir may enhance the dissolution of carbonates, even in the absence of an acid source (Bischoff et al. 1994). Therefore, hypogenic karstic phenomena associated with the local network of fractures may enhance the permeability and the water flux, as shown in several carbonate reservoir thermal systems around the world (Goldscheider et al. 2010).

The relief of the Euganei Hills and Berici Mountains (maximum elevation $603 \mathrm{~m}$ a.s.l. and $445 \mathrm{~m}$ a.s.l., respectively) cannot constitute the infiltration area of the parent meteoric water because they do not reach the infiltration elevation of 1,500 $\mathrm{m}$ a.s.l. suggested by the stable isotope analysis (Gherardi et al. 2000). North of the middle part of the circuit, the Veneto Prealps to the east of the Schio-Vicenza Fault may constitute the recharge area of the Euganean Geothermal System. The hypothesized recharge area is located in the Sette Comuni and Tonezza Plateaux and the relief surrounding the area features an elevation range of $87 \mathrm{~m}$ a.s.1. to 2,341 $\mathrm{m}$ a.s.1., a mean elevation of $1,317 \mathrm{~m}$ a.s.l., and a surface area of $880 \mathrm{~km}^{2}$ (Fig. 3A). This choice is supported by the following observations: i) the elevation of the area is consistent with the stable isotope composition; ii) the Mesozoic limestone and dolomite formations of the main thermal aquifer crop out extensively in the area; iii) the plateaux are characterized by fractures and karstic conduits that permit the deep infiltration of the meteoric water; and iv) the hydrological mass balance of the area (Aurighi et al. 2004) indicates that $23 \%$ of the infiltration $(260 \mathrm{~mm} / \mathrm{y})$ is not balanced by the discharge of springs located at the base of the relief, producing a potential recharge 
for the thermal system of approximately $230^{*} 10^{6} \mathrm{~m}^{3} / \mathrm{y}$, enough to feed the $17^{*} 10^{6}$ $\mathrm{m}^{3} / \mathrm{y}$ of thermal water exploited in the EGF. The Sette Comuni and Tonezza Plateaux are bounded to the south by the south-vergent Bassano Thrust and the associated asymmetric anticline (Fig. 3A; Fig. 3B), which provide the continuity of the thermal aquifer from the infiltration to the outflow area of the thermal system (Fig. 3B).

Summarizing the proposed model, the parent meteoric water infiltrates in the Sette Comuni and Tonezza Plateaux as a result of the high secondary permeability of the outcropping rocks. The water flows to the south in a Mesozoic limestone and dolomite reservoir, reaching a depth of approximately 3,000 $\mathrm{m}$ and increasing in temperature to approximately $100{ }^{\circ} \mathrm{C}$ due to the normal geothermal gradient and exothermic reactions between the anhydrite-bearing Permian-Triassic evaporitic formations and the water. The Schio-Vicenza Fault and its highly permeable damage zone are the path for the migration of the thermal water. The hot water intercepts the interaction zone (relay ramp) between the faults of the Schio-Vicenza fault system in the EGF area. This structure increases the rock fracturing, permits the development of high permeability and enhances the migration of thermal water to the surface. The ascent of the thermal fluids in the EGF occurs rapidly, as indicated by the measured temperatures in the thermal wells (up to $95^{\circ} \mathrm{C}$ ), which approach the temperature of the reservoir inferred via geothermometers $\left(80-100^{\circ} \mathrm{C}\right)$. The residence time of the thermal water is greater than 60 years and probably in the range of several thousand years, as shown by ${ }^{3} \mathrm{H}$ and ${ }^{14} \mathrm{C}$ analysis (Piccoli et al. 1973; Sartori et al. 1997; Gherardi et al. 2000; Boaretto et al. 2003). The results of the U-series and stable isotope geochemical analyses performed on the travertine of Montirone Hill (Pola et al. 2014a) corroborate the proposed model. The analyses found: i) a low uranium content (3-12 ppb) characterized by a ${ }^{234} \mathrm{U} /{ }^{238} \mathrm{U}$ activity ratio higher than unity; and ii) $\delta^{18} \mathrm{O}$ values less than 0 and $\delta^{13} \mathrm{C}$ values greater than 0 . These data are typical of deep hydrothermal circulation characterized by a long path at depth and long-term water-rock interaction, in accordance with the proposed conceptual model of the Euganean Geothermal System. In addition, the age of the first meter of the travertine deposit (20 to $34 \mathrm{ka}$; Upper Pleistocene; Pola et al. 2014a) confirms the long activity of the Euganean Geothermal System, which must have been active at least since 34 ka to allow the thermal fluid flow and the deposition of the travertine.

\section{Numerical implementation of the conceptual model}

The equivalent porous medium (EPM) approach is used to reproduce the Euganean Geothermal System with the HYDROTHERM code (Kipp et al. 2008). This approach, often referred to as equivalent continuum (Bear 1972), considers together the rock matrix and the fractures and assigns them average hydrodynamic and thermal properties over a volume that is sufficiently large to be considered statistically representative (Representative Elementary Volume, or REV; Long et al. 1982). Most authors agree that the EPM approach is particularly suited for flow systems at a regional scale and especially for karstic aquifers (Scanlon et al. 2003). However, this 
approach can give erroneous results in terms of the flow directions or mass balance in a more detailed scale or in heterogeneous conditions; in these situations, alternative strategies must be adopted (Garzonio et al. 2014). The scale of the thermal system, the spatial distribution of the hydrogeologic data and their degree of detail make the EPM approach particularly suitable to simulating the Euganean Geothermal System.

A two-dimensional model domain is discretized from the standard cross-section of the Euganean Geothermal System, neglecting the magmatic bodies in the EGF subsurface, into 160 columns and 12 layers, resulting in 1,920 square cells with faces that are $0.5 \mathrm{~km}$ in length. The input parameters values of the thermal system formations [porosity (n), permeability $(\mathrm{K})$, thermal conductivity $(\lambda)$, specific heat capacity (c), density $(\rho)$ and compressibility $(\beta)$ ] were obtained through literature research (e.g. Pasquale and Verdoya 1990; Domenico and Schwartz 1998; Scharli and Rybach 2001; Vosteen and Schellschmidt 2003). The applied boundary conditions (Fig. 4) are: i) recharge from precipitation of $260 \mathrm{~mm} / \mathrm{y}$ (Aurighi et al. 2004) at the top of the domain corresponding to the recharge area; ii) a seepage face, which permits the outflow of groundwater from the simulated region and maintains the enthalpy of thermal waters, at the top of the domain in the area of the relay ramp corresponding to the EGF; iii) a basal heat flux of $100 \mathrm{~mW} / \mathrm{m}^{2}$ (Della Vedova et al. 2001) at the bottom of the domain; iv) constant pressure and temperature values at the other boundaries; and v) two point sources with a total outflow rate of $17^{*} 10^{6} \mathrm{~m}^{3} / \mathrm{y}$, representing the present exploitation from the subsurface of EGF. The initial conditions are: i) a pressure of 1 atm and a temperature of $15^{\circ} \mathrm{C}$ at the top of the domain; and ii) a hydrostatic distribution of pressure and a geothermal gradient of $30^{\circ} \mathrm{C} / \mathrm{km}$ in the remaining layers. The simulations are in transient mode and are discretized into two periods: i) an initial period of variable time duration during which the water flux is affected only by the boundary condition; and ii) a second period of 100 years during which the water flux is also affected by the point sources. The duration of the first simulation step is adjusted using a trial and error method until stable conditions of fluid flow and temperature in the EGF subsurface are obtained.

The numerical simulations are conducted starting with an explorative simulation using initial educated guesses for the parameters and an isotropic permeability. Sub-

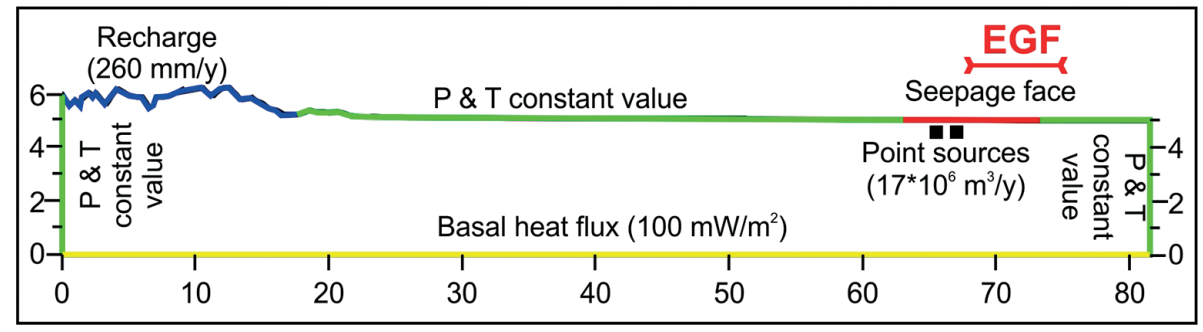

Fig. 4

Boundary conditions applied to the numerical model 
sequently, a manual calibration is performed to obtain the configuration of parameters that results in a subsurface EGF temperature similar to the one measured in the thermal wells. Hurwitz et al. (2003) stated that the permeability and the thermal conductivity of the rock units mainly affect the fluid and heat flux. The performed calibration is focused on these two parameters, and it is conducted by means of changing the mean values, which were used in the initial simulation, to the minimum and the maximum values obtained during the literature research. The thermal conductivity of the Quaternary alluvial cover and the pre-Permian crystalline basement are omitted from the calibration because a slight variation in the thermal conductivity values occurs.

\section{Numerical simulation results}

The explorative simulation (Fig. 5), with the initially guessed parameter values and an isotropic permeability, is run for a first period of 5,000 years without exploitation and for a second period of 100 years with the fluid exploitation. The initial temperatures of the formations in the EGF subsurface are as follows: $15{ }^{\circ} \mathrm{C}$ in the Quaternary alluvial cover, $31^{\circ} \mathrm{C}$ in the Mesozoic (i.e. Jurassic and Cretaceous) carbonate formations, $62{ }^{\circ} \mathrm{C}$ in the Upper Triassic dolomite formations, up to $145^{\circ} \mathrm{C}$ in the pre-Permian crystalline basement. Two increases in the temperatures of the EGF thermal aquifer are observed during this simulation (Fig. 5A): i) increases of $28^{\circ} \mathrm{C}$ in the Quaternary alluvial cover, $20^{\circ} \mathrm{C}$ in the Mesozoic carbonate formations and $3{ }^{\circ} \mathrm{C}$ in the Upper Triassic dolomite formations from approximately 3,000 years until the end of the first simulation period; and ii) increases of $12^{\circ} \mathrm{C}$ in the Quaternary cover, $4{ }^{\circ} \mathrm{C}$ in the Mesozoic carbonate formations and $0.5^{\circ} \mathrm{C}$ in the Upper Triassic dolomite formations during the second simulation period. The first increment is related to an upward vertical flux of the thermal waters from the lower part of the simulated region, which is probably driven by the seepage face boundary condition applied at the top of the domain. A horizontal flux occurs together with the vertical flux, suggesting the development of convective cells in the EGF subsurface that favors the rise of the isotherms during the first simulation period (Fig. 5B). In contrast, the second increase can be ascribed to the enhanced flow of hot fluids toward the alluvial cover (Fig. 5B) due to the pumping simulated by the point sources.

The maximum temperature obtained from the first simulation in the EGF thermal aquifer is approximately $60{ }^{\circ} \mathrm{C}$ and does not reach the observed temperatures of $70-80$ ${ }^{\circ} \mathrm{C}$. Therefore, a calibration of permeability and thermal conductivity is performed in an attempt to approach the real temperatures. The simulations are conducted using the same simulation time as the first simulation, and the results are compared. The analysis of the permeability indicates that, in general, the mean value of permeability results in higher temperature values for the EGF thermal aquifer. In contrast, the analysis of the thermal conductivity shows that higher temperatures in the EGF subsurface result from the use of a particular configuration of values featuring low values for the formations of the thermal aquifer ( $\lambda$ from 2.1 to $3.1 \mathrm{~W} / \mathrm{m} * \mathrm{~K}$ ) and high values 
for the formation below the thermal aquifer ( $\lambda$ from 3.2 to $4.7 \mathrm{~W} / \mathrm{m} * \mathrm{~K}$ ). Thermal conductivity is the property of a material to conduct heat. Therefore, high values for the formations below the thermal aquifer cause a higher rate of heat transfer towards the thermal aquifer, whereas low values for the aquifer itself allow it to retain the heat inside the formations. The configuration of values after the calibration is tested in a simulation of 15,100 years $(15,000$ years without exploitation and 100 years of thermal fluid exploitation) because the simulation time of 5,100 years does not appear to provide a stable distribution of temperature and water flux in the EGF. The model (Fig. $6 \mathrm{~A}$ ) is affected by a chaotic water flux until 5,000 years and the subsequent develop-

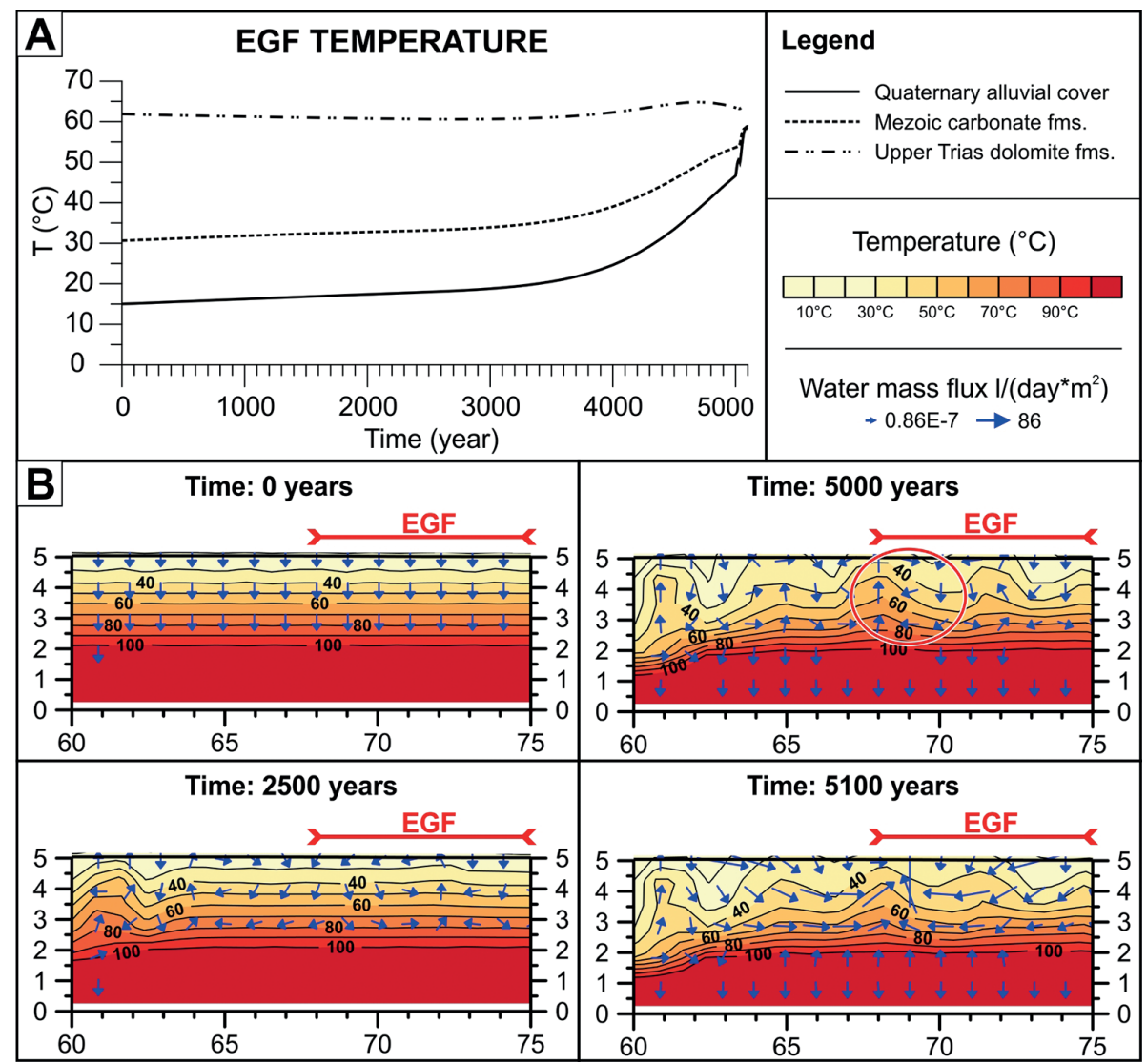

Fig. 5

Results of the simulation performed using initial guesses for the parameters. (A) Simulated temperatures measured in the formations of the thermal aquifer in the EGF subsurface. A gradual increase in temperature is observed in the thermal aquifer, which reaches temperatures between $50{ }^{\circ} \mathrm{C}$ and $60{ }^{\circ} \mathrm{C}$. (B) Simulated temperature and water flux at different time steps in the EGF subsurface. The water flux indicates the development of convective cells (red circle) that permit the rising of the isotherms and an increase in temperature 
ment of large convective cells that favors a homogenization of temperatures between $20{ }^{\circ} \mathrm{C}$ and $40{ }^{\circ} \mathrm{C}$ in the EGF subsurface (15,000 years), except for a small $50-60{ }^{\circ} \mathrm{C}$ plume in the middle part (Fig. 7A). Therefore the permeability of the carbonate ther-

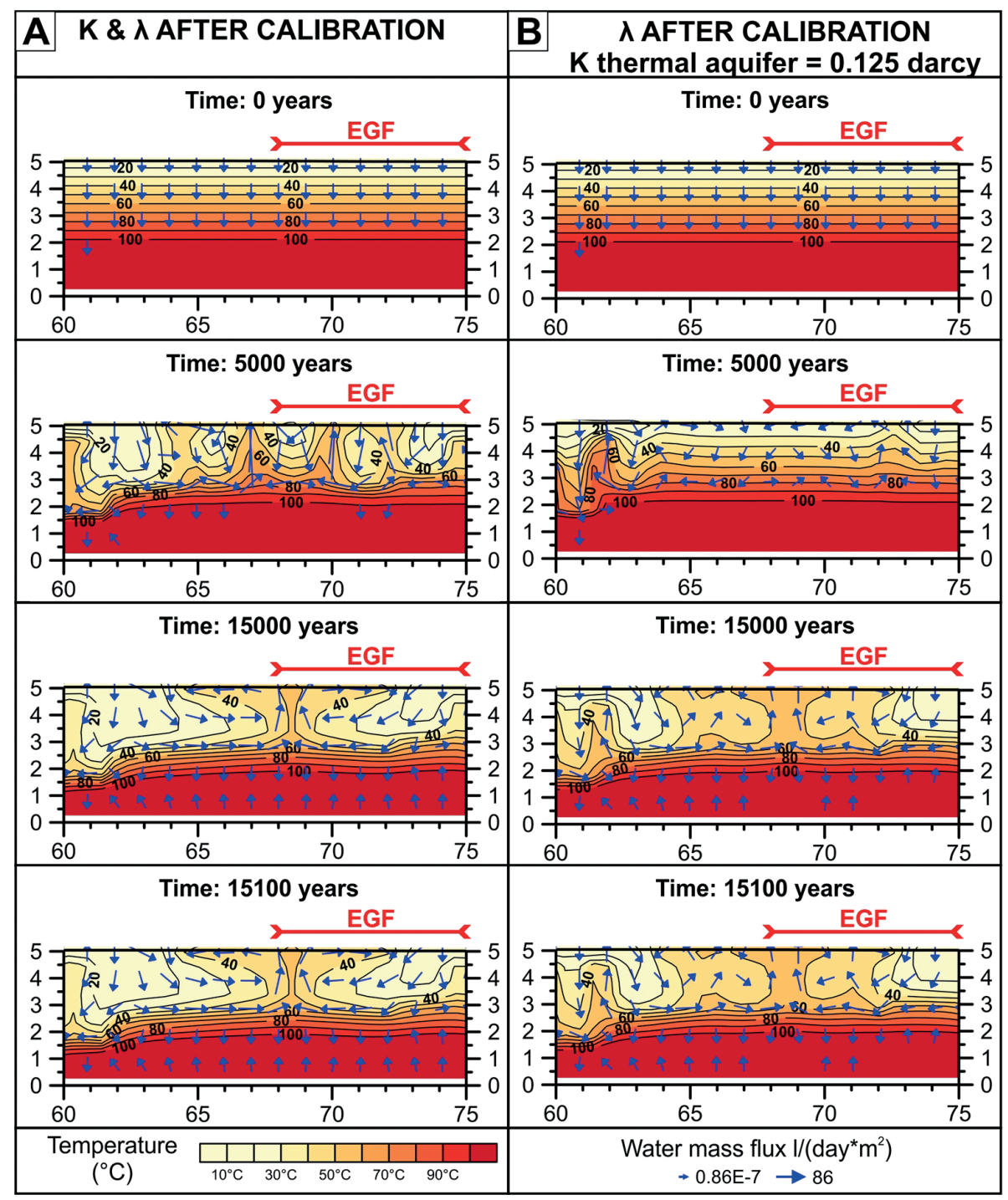

Fig. 6

Results of the simulations performed after the calibration of permeability and thermal conductivity (A) and using a reduced permeability for the thermal aquifer (B). The reduced permeability results in a better development of temperatures in the EGF subsurface, as shown by the isotherms $40{ }^{\circ} \mathrm{C}$ and $50{ }^{\circ} \mathrm{C}$ at $\mathrm{t}=$ 15,000 years 
mal aquifer is slightly reduced ( $\mathrm{K}=0.125$ Darcy) with the aim of obtaining a slower and less chaotic development of the water flux. This configuration is tested in a new simulation together with the previous configuration of the thermal conductivity and for the same simulation time. The simulation yields a temperature zone of $40{ }^{\circ} \mathrm{C}$ to $60{ }^{\circ} \mathrm{C}$ in the EGF thermal aquifer (Fig. 6B) that is more homogeneous and wider than the previous simulations (Fig. 5; Fig. 6A). Therefore, a slightly reduced permeability seems to develop higher temperatures in the EGF thermal aquifer, although the obtained temperatures are still lower than the measured $70-80{ }^{\circ} \mathrm{C}$.

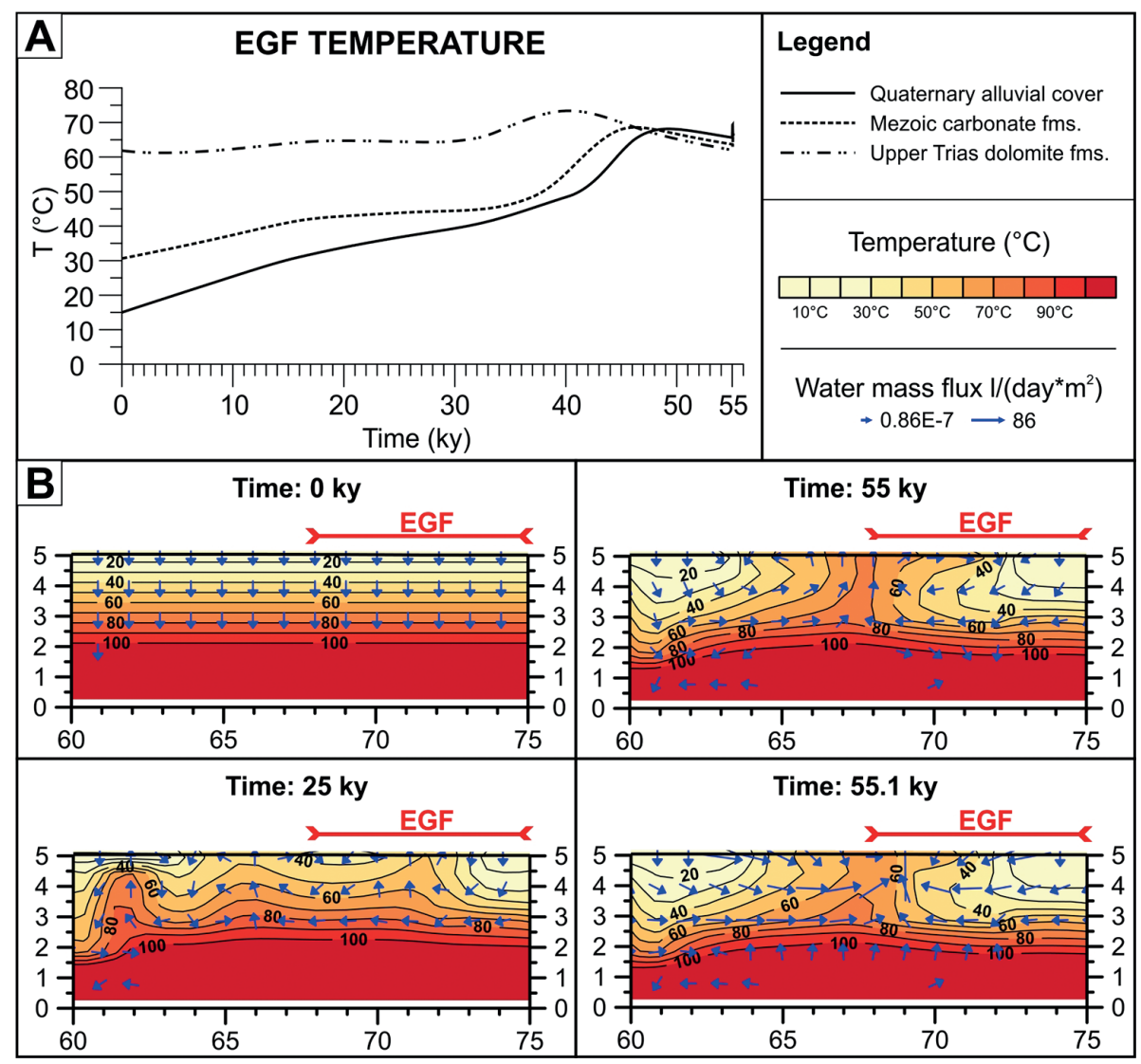

Fig. 7

Results of the simulation performed using the calibrated parameters and an anisotropy factor of 0.2 $\left(\mathrm{k}_{\mathrm{z}} / \mathrm{k}_{\mathrm{x}}\right.$; Table 1). (A) Simulated temperatures measured in the formations of the thermal aquifer in the EGF subsurface. This model results in a gradual increase in temperature that generates a maximum temperature of $74{ }^{\circ} \mathrm{C}$ at $\mathrm{t}=40,000$ years in the Upper Triassic dolomite formations and approximately $65^{\circ} \mathrm{C}$ throughout the thermal aquifer at the end of the simulation. (B) Simulated temperature and water flux at different time steps in the EGF subsurface. A $60-70{ }^{\circ} \mathrm{C}$ plume develops and features a maximum surficial temperature of $72{ }^{\circ} \mathrm{C}$ at $\mathrm{t}=55,000$ years 
The calibration of the parameters proceeded through the test of different anisotropies of permeability with the aim of decreasing the fluid flux, which appears to favor the development of higher temperatures. The best result is obtained using the previous configuration of thermal conductivity, the reduced permeability for the carbonate formations of the thermal aquifer $(\mathrm{K}=0.125$ Darcy) and an anisotropy factor of $0.2\left(\mathrm{k}_{\mathrm{z}} / \mathrm{k}_{\mathrm{x}}\right.$; Table 1$)$. The length of this simulation is 55,100 years $(55,000$ years without exploitation and 100 years of exploitation), which is in agreement with the age of the travertine in Abano Terme (20-34 ky; Pola et al. 2014a) and the long residence time of the Euganean thermal water (thousands of years). The temperatures of the EGF thermal aquifer increase gradually reaching a maximum value of $74{ }^{\circ} \mathrm{C}$ in the Upper Triassic dolomite formations at $t=40,000$ years (Fig. 7A). Subsequently the temperature in the Upper Triassic formations decreases, whereas the temperatures in the Quaternary alluvial cover and the Mesozoic (i.e. Jurassic and Cretaceous) carbonate formations continue to rise. A homogeneous temperature of approximately $65^{\circ} \mathrm{C}$ throughout the EGF thermal aquifer (Fig. 7A) is obtained at the end of the first simulation period $(t=55,000$ years). The distribution of the temperatures in the EGF subsurface (Fig. 7B) exhibits a slight increase of approximately $10{ }^{\circ} \mathrm{C}$ near the surface until 25,000 years. Subsequently, two large convective cells with temperatures between $30^{\circ} \mathrm{C}$ and $60^{\circ} \mathrm{C}$ develop, and they are divided by a plume with temperatures between $60{ }^{\circ} \mathrm{C}$ and $70{ }^{\circ} \mathrm{C}$ (a maximum temperature of $72^{\circ} \mathrm{C}$ is observed in the middle part of the plume near the surface at the end of the first simulation period, $\mathrm{t}=55,000$ years), which are similar to the observed temperature values.

Table 1

Values of parameters for the different formations used in the calibrated simulation

\begin{tabular}{llllllll}
\hline & Lithology & $\mathrm{n}$ & $\mathrm{K}$ & $\lambda$ & $\mathrm{c}$ & $\rho$ & $\beta$ \\
\hline 1 & Sands-Clays & 0.3 & 13.5 & 1.35 & 860 & 2,500 & $2.00 \mathrm{E}-08$ \\
\hline 2 & Sandstones-Limestones & 0.15 & 0.31 & 2.77 & 860 & 2,550 & $1.4 \mathrm{E}-08$ \\
\hline 3 & Volcanic rocks & 0.19 & 3.12 & 1.85 & 825 & 2,900 & $5 \mathrm{E}-10$ \\
\hline 4 & Limestones & 0.15 & 0.125 & 2.68 & 845 & 2,620 & $1.4 \mathrm{E}-08$ \\
\hline 5 & Limestones & 0.15 & 0.125 & 2.1 & 845 & 2,620 & $1.50 \mathrm{E}-08$ \\
\hline 6 & Dolomite rocks & 0.12 & 0.125 & 3.1 & 920 & 2,830 & $1.10 \mathrm{E}-08$ \\
\hline 7 & Sandstones-Volcanic rocks & 0.11 & 0.156 & 2 & 810 & 2,100 & $5.00 \mathrm{E}-08$ \\
\hline 8 & Sandstones-Evaporites & 0.02 & $8.84 \mathrm{E}-04$ & 4.72 & 885 & 2,350 & $1.3 \mathrm{E}-08$ \\
\hline 9 & Phyllites & 0.04 & $3.1 \mathrm{E}-09$ & 3.25 & 870 & 2,760 & $1.6 \mathrm{E}-08$ \\
\hline
\end{tabular}

The parameters are as follows: $\mathrm{n}$, porosity $(-) ; \mathrm{K}$, permeability (Darcy); $\lambda$, thermal conductivity $(\mathrm{W} / \mathrm{m} * \mathrm{~K})$; $\mathrm{c}$, specific heat capacity $(\mathrm{J} / \mathrm{kg} * \mathrm{~K}) ; \rho$, density $\left(\mathrm{kg} / \mathrm{m}^{3}\right) ; \beta$, compressibility $\left(\mathrm{Pa}^{-1}\right)$. The formations are as follows: 1, Quaternary alluvial cover; 2, Oligocene-Miocene clastic-carbonate formations; 3, Paleogene volcanic rocks; 4, Paleocene-Eocene carbonate formations: 5, Mesozoic (i.e. Jurassic and Cretaceous) carbonate formations; 6, Upper Triassic dolomite formations; 7, Middle Triassic clastic-volcanic formations; 8, Permian-Triassic clastic-evaporitic formations; 9, pre-Permian crystalline basement 
Focusing on the other parts of the model (Fig. 8), we observed the following:

- In the recharge area, a constant downward water flux develops in the outcropping formations, while a horizontal downstream water flux develops beneath these formations. The vertical flux causes an approximately $20{ }^{\circ} \mathrm{C}$ decrease in the temperature of the formations that crop out in the recharge area.

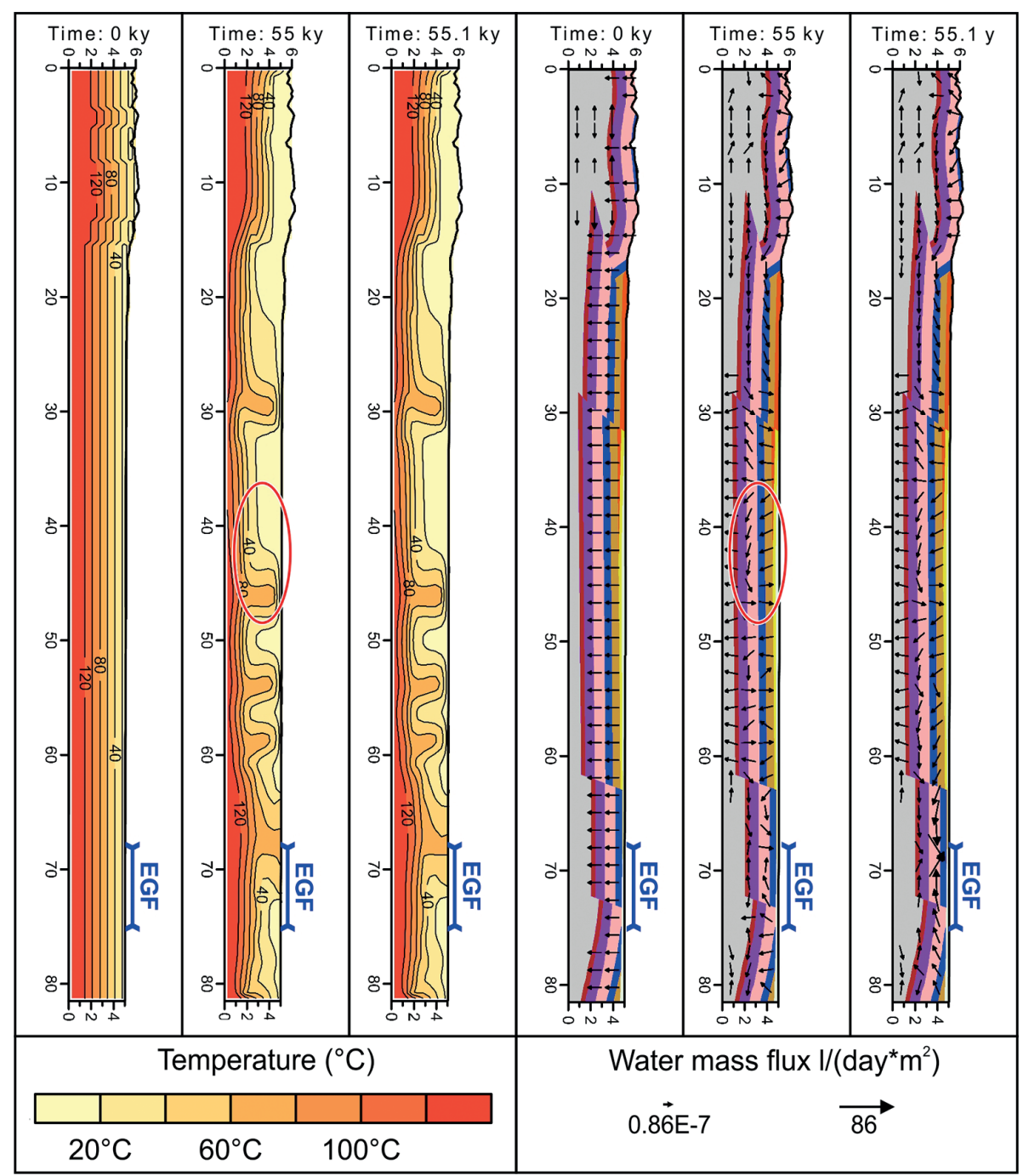

Fig. 8

Temperature and fluid flow obtained for the entire thermal system using the calibrated parameters and an anisotropy factor of $0.2\left(\mathrm{k}_{\mathrm{z}} / \mathrm{k}_{\mathrm{x}}\right.$; Table 1$)$. The topographically driven fluid flow is enhanced by the development of convective cells (red circle). 
- In the middle part, the development of regional-scale convective cells affects the distribution of temperatures and water flow. The convective cells both decrease and increase the local temperatures on the order of approximately $20-40{ }^{\circ} \mathrm{C}$ during the first simulation period. The Middle Triassic volcanic and the Permian-Triassic clastic-evaporitic formations are also affected by the convective cells, which likely allow a mixing of fluids located at different depths, similar to the intra-formational fluxes discussed in the conceptual model.

In conclusion, the simulated temperatures of $60-70{ }^{\circ} \mathrm{C}$ approach the observed temperatures of $70-80{ }^{\circ} \mathrm{C}$ measured in the thermal wells of the EGF. In addition, the results of this last simulation are corroborated by: i) the simulated time, which is in agreement with the age of the travertine of the Montirone Hill (20-34 ky); and ii) the development of a flux driven by the topographical gradient, as suggested by the proposed conceptual model.

\section{Conclusions}

This work re-examines the model of the Euganean Geothermal Field (EGF), one of the most important thermal fields in northeastern Italy, taking into account recent data on the thermal field and on the thermal waters. The proposed model is a regional-scale, tectonically controlled conceptual model that covers an 80-km-long and $20-\mathrm{km}$-wide area in central Veneto (Fig. 3). The parent meteoric water infiltrates in the Veneto Prealps to the east of the SVFS and approximately $80 \mathrm{~km}$ to the north of the EGF in the Sette Comuni and Tonezza Plateaux and the relief surrounding this area. The water flows to the south in a Mesozoic limestone and dolomite reservoirs and reaches a depth of approximately 3,000 $\mathrm{m}$. The normal geothermal gradient and exothermic water-rock interactions with the anhydrite in Permian-Triassic evaporitic formations below the reservoir increase the temperature of the water to $100{ }^{\circ} \mathrm{C}$. The thermal water flux is enhanced by the high permeability of the Schio-Vicenza Fault damage zone. In the EGF area, the thermal water is intercepted by an interaction zone (relay ramp) between two faults (i.e. the Schio-Vicenza and Conselve-Pomposa Faults), which produces a local fracture mesh and increases the local permeability and the water flux. The upwelling of the thermal water occurs rapidly, as suggested by the similarity between the measured temperatures in the EGF thermal wells and the temperature of the reservoir. Subsequently, the thermal water spreads horizontally through fractured layers in the Dolomia Principale, Calcari Grigi and Maiolica Formations or locally rises up to shallow sandy layers in the Quaternary alluvial cover, forming hydraulically connected thermal aquifers located at different depths.

The proposed conceptual model is validated by numerical simulations conducted using an EPM approach with the HYDROTHERM code. This code permits the development of simple models with long simulated durations and requires minimal computational effort. The best result is obtained after a calibration of the per- 
meability and the thermal conductivity of the formations involved in the thermal system. This analysis yields a configuration of parameters that results in higher temperatures in the formations of the EGF thermal aquifer. The best simulation, carried on a simulation length of 55,100 years, shows a $60-70{ }^{\circ} \mathrm{C}$ plume in the EGF area, and a maximum temperature of $72{ }^{\circ} \mathrm{C}$ is observed in the middle part of the plume near the surface $(\mathrm{t}=55,000$ years; Fig. 7B). These values approach the $70-80{ }^{\circ} \mathrm{C}$ measured in the EGF thermal wells, constraining the performed model. The two-dimensional numerical model does not take into account certain parameters (e.g. the permeability and geometry of the damage zone of the Schio-Vicenza Fault, the higher permeability in the EGF area related to the interaction zone, the occurrence of magmatic bodies and karstic conduits enhancing the water flux in the EGF subsurface, the exothermic reactions between the evaporitic rocks and the thermal water) that may influence the development of the water flux, the temperature and the time scale of the simulations. However, this is the first numerical model developed for the Euganean Geothermal System, and the calculated temperatures, in agreement with the observed temperatures, demonstrate that this conceptual model can be simulated in a realistic way through numerical modeling of groundwater flow and heat transport.

\section{Acknowledgements}

This work was funded by the University of Padova (ex 60\% "Modello idrogeologico e geologico strutturale dell'area termale Euganea" grant to P. Fabbri, the Athenaeum project "A new conceptual model of the Euganean Geothermal System performed using a multidisciplinary approach"; No.: CPDA102312; year: 2010, grant to D. Zampieri) and the CariPaRo Foundation $\mathrm{PhD}$ thesis grant to M. Pola.

\section{References}

Antonelli R., P. Fabbri 1988: Analysis and comparison of some values of transmissivity, permeability and storage from the Euganean Thermal Basin. - In: 21st IAH Congress Karst Hydrogeology and Karst Environment Protection Abstract Book, Giulin, Cina, pp. 707-718.

Antonelli, R., G. Barbieri, G.V. Dal Piaz, A. Dal Prá, V. De Zanche, P. Grandesso, P. Mietto, R. Sedea, A. Zanferrari 1990: Carta geologica del Veneto 1:250.000 e relative Note Illustrative. - S.E.L.C.A., Firenze.

Antonelli, R., E. Callegari, P. Fabbri, R. Sedea 1993: Recenti contributi alla conoscenza dell'idrostruttura del bacino termale euganeo (Padova). - GEAM, 79, pp. 49-55.

Antonelli R., A. Baglioni, P. Fabbri, P. Grandesso, V. Iliceto, L. Scaramuzza, R. Sedea 1994: Applicazioni del "gamma ray log" eseguito in un pozzo a carotaggio continuo nell'area termale Euganea (Padova). - Geologica Romana, 30, 217-226.

Aurighi, M., A. Cisotto, A. Dal Prá, M. Janza, R. Mariani, M. Nordico, C. Soccorso, D. Steccanella, G. Barbieri 2004: Carta idrogeologica dell'Altopiano dei Sette Comuni. - Regione Veneto, Giunta Regionale, $31 \mathrm{p}$. 
Baietto, A., P. Cadoppi, G. Martinotti, P. Perello, P. Perrochet, F.D. Vuataz 2008: Assessment of thermal circulation in strike-slip fault systems: the Terme di Valdieri case. - Geological Society of London Special Publications, 299, pp. 317-339.

Bear, J. 1972: Dynamics of fluids in porous media. - American Elseviers Publishing Company, New York, 764 p.

Bischoff, J.L., R. Julia, W.C. Shanks, R.J. Rosenauer 1994: Karstification without acid; bedrock dissolution by gypsum-driven dedolomitization. - Geology, 22, pp. 995-998.

Boaretto, E., I. Carmi, P. Fabbri, J. Heinemeier, S. Sartori, A.E. Sveinbjornsdottir, Y. Yechieli 2003: Radiocarbon in thermal and fresh groundwater in Veneto Region, Northern Italy. - Proceedings of the XVIIIth International Radiocarbon Conference.

Burrato, P., M. Poli, P. Vannoli, A. Zanferrari, R. Basili, F. Galadini 2008: Sources of Mw 5+ earthquakes in northeastern Italy and western Slovenia: An updated view based on geological and seismological evidence. - Tectonophysics, 453, pp. 157-176.

Curewitz, D., J.A. Karson 1997: Structural setting of hydrothermal outflow: Fracture permeability maintained by fault propagation and interaction. - Journal of Volcanology and Geothermal Research, 79, pp. 149-168.

D’Agostino, N., D. Cheloni, S. Mantenuto, G. Selvaggi, A. Michelini, D. Zuliani 2005: Strain accumulation in the southern Alps (NE Italy) and deformation at the northeastern boundary of Adria observed by CGPS measurements. - Geophysical Research Letters, 32, 19 p.

Della Vedova, B., S. Bellani, G. Pellis, P. Squarci 2001: Deep temperatures and subsurface heat flow distribution. - In: Vai, G.B., I.P. Martini (Eds): Anatomy of an Orogen: the Apennines and the Adjacent Mediterranean Basin, pp. 65-76.

Domenico, P.A., W. Schwartz 1998: Physical and Chemical Hydrogeology, Second Edition. - Wiley, New York, 824 p.

Fabbri, P. 1997: Transmissivity in the Euganean Geothermal Basin: a geostatistical analysis. Groundwater, 35, pp. 881-887.

Fabbri, P. 2001: Probabilistic assessment of temperature in the Euganean geothermal area (Veneto region, NE Italy). - Mathematical Geology, 33, pp. 745-760.

Fabbri P., G. Matteotti 1989: Analisi su alcune metodologie di calcolo della permeabilità nell'acquifero Euganeo. - Idrotecnica, 3, pp. 107-114.

Fabbri P., G. Matteotti 1992: Interpretazione di prove di pompaggio in pozzo: utilizzo combinato dei metodi della curva tipo e della derivata della pressione. - Idrotecnica, 3, pp. 119-126.

Fabbri, P., S. Trevisani 2005: Spatial distribution of temperature in the geothermal Euganean field (NE, Italy): a simulated annealing approach. - Geothermics, 34, pp. 617-631.

Fabbri, P., C. Soccorso 2007: La risposta dei livelli potenziometrici allo sfruttamento del campo geotermico Euganeo (PD). - Giornale di Geologia Applicata, 5, pp. 115-124.

Fantoni, R., D. Cattelani, S. Merlini, S. Rogledi, S. Venturini 2002: La registrazione degli eventi deformativi cenozoici nell'avampaese Veneto-Friuliano. - Memorie della Società Geologica Italiana, 57, pp. 301-313.

Faulkner, D.R., C.A.L. Jackson, R.J. Lunn, R.W. Schlische, Z.K. Shipton, C.A.J. Wibberley, M.O. Withjack 2010: A review of recent developments concerning the structure, mechanics and fluid flow properties of fault zones. - Journal of Structural Geology, 32, pp. 1557-1575.

Ferri, F., R. Ventura, F. Coren, C. Zanolla 2005: Gravity Map of Italy and Surroundings Seas 1:1250000. - APAT Agenzia per la protezione dell'ambiente e per i servizi tecnici. Dipartimento Difesa del Suolo, 15 p.

Ferrill, D.A., A.P. Morris 2001: Displacement gradient and deformation in normal fault systems. Journal of Structural Geology, 23, pp. 619-638.

Garzonio, C.A., L. Piccinini, A. Gargini 2014: Groundwater Modeling of Fractured Aquifers in Mines: The Case Study of Gavorrano (Tuscany, Italy). - Rock Mechanics and Rock Engineering, 47/3, pp. 905-921.

Gherardi, F., C. Panichi, S. Caliro, G. Magro, M. Pennisi 2000: Water and gas geochemistry of the Euganean and Berician thermal district (Italy). - Applied Geochemistry, 15, pp. 455-474. 
Goldscheider, N., J. Mádl-Szőnyi, A. Erőss, E. Schill 2010: Review: thermal water resources in carbonate rock aquifers. - Hydrogeology Journal, 18, pp. 1303-1318.

Hurwitz, S., K.L. Kipp, S. Ingebritsen, M. Reid 2003: Groundwater flow, heat transport, and water table position within volcanic edifices: Implications for volcanic processes in the Cascade Range. - Journal of Geophysical Research: Solid Earth, 108/12, 19 p.

Ingebritsen, S.E., S.A. Rojstaczer 1996: Geyser periodicity and the response of geysers to deformation. - Journal of Geophysical Research, 101, pp. 21891-21905.

Kipp, K.L., P.A. Hsieh, S.R. Charlton 2008: Guide to the revised groundwater flow and heat transport simulator. - HYDROTHERM-3. U.S.G.S. Techniques \& Methods, 6-A25, 160 p.

Long, J.J., J. Imber 2011: Geological controls on fault relay zone scaling. - Journal of Structural Geology, 33, pp. $1790-1800$.

Long, J.C.S., J.S. Remer, C.R. Wilson, P.A. Witherspoon 1982: Porous media equivalents for networks of discontinuous fractures. - Water Resources Research, 18, pp. 645-658.

Masetti, D., R. Fantoni, R. Romano, D. Sartorio, E. Trevisani 2012: Tectonostratigraphic evolution of the Jurassic extensional basins of the eastern southern Alps and Adriatic foreland based on an integrated study of surface and subsurface data. - AAPG Bulletin, 96, pp. 2065-2089.

Norton, D., C. Panichi 1978: Determination of the sources and circulation paths of thermal fluids: the Abano region, northern Italy. - Geochimica et Cosmochimica Acta, 42, pp. 1283-1294.

Pasquale, V., M. Verdoya 1990: Geothermal regime of the Po basin, Italy. - Società Geologica Italiana, Volume Speciale, 1, pp. 135-143.

Peacock, D.C.P., D.J. Sanderson 1994: Geometry and development of relay ramps in normal fault systems. - AAPG Bulletin, 78, pp. 147-165.

Peacock, D.C.P., D.J. Sanderson 1995: Strike-slip relay ramps. - Journal of Structural Geology, 17, pp. 1351-1360.

Perello, P., M. Marini, G. Marinotti, J. Hunziker 2001: The thermal circuit of The Argentera Massif (Western Alps, Italy). An example of low-enthalpy geothermal resources controlled by Neogene alpine tectonics. - Eclogae Geologicae Helvetiae, 94, pp. 74-94.

Piccoli, G., A. Dal Prá, R. Sedea, R. Bellati, E. Di Lallo, R. Cataldi, P. Baldi, G.C. Ferrara 1973: Contributo alla conoscenza del sistema idrotermale Euganeo-Berico. - Atti Accademia Nazionale Lincei, 9, pp. 103-131.

Pola M., P. Fabbri, A. Gandin, M. Soligo, P. Tuccimei, R. Deiana, D. Zampieri 2011: The Montirone travertine mound: a multidisciplinary approach: Implication for the Euganean Geothermal Field. Rendiconti online della Soc. Geol. It., 16, pp. 28-29.

Pola M., P. Fabbri, L. Piccinini, D. Zampieri 2013: A new hydrothermal conceptual and numerical model of the Euganean Geothermal system, NE Italy. - Rendiconti online della Soc. Geol. It., 24, pp. 251-253.

Pola, M., A. Gandin, P. Tuccimei, M. Soligo, R. Deiana, P. Fabbri, D. Zampieri 2014a: A multidisciplinary approach to understanding carbonate deposition under tectonically controlled hydrothermal circulation: a case study from a recent travertine mound in the Euganean Hydrothermal System, northern Italy. - Sedimentology, 61, pp. 172-199.

Pola, M., A. Ricciato, R. Fantoni, P. Fabbri, D. Zampieri 2014b: Architecture of the western margin of the North Adriatic foreland: the Schio-Vicenza fault system. - Italian Journal of Geoscience, 133, pp. 223-234.

Pola M., P. Fabbri, L. Piccinini, E. Marcolongo, A. Rosignoli, D. Zampieri, A. Roghel, S. Onisto, E. Zampieri 2015: Anthropic impact on thermal aquifer: the case study of the Euganean Geothermal Field (NE Italy). - Rendiconti online della Soc. Geol. It., 35, pp. 240-243.

Rotevatn, A., H. Fossen, J. Hesthammer, T.E. Aas, J.A. Howell 2007: Are relay ramps conduits for fluid flow? Structural analysis of a relay ramp in Arches National Park, Utah. - Geological Society of London Special Publications, 270, pp. 55-71.

Sartori, S., E. Boaretto, P. Fabbri, A.E. Sveinbjornsdottir, J. Heinemeier 1997: 14C content of Euganean geothermal waters (Veneto, Italy). - In: Proceedings of the XVIth International Radiocarbon Conference, Groningen. 
Scanlon, B.R., R.E. Mace, M.E. Barrett, B. Smith 2003: Can we simulate regional groundwater flow in a karst system using equivalent porous media models? Case study, Barton Springs Edwards aquifer, USA. - Journal of Hydrology, 276, pp. 137-158.

Scharli, U., L. Rybach 2001: Determination of the specific heat capacity on rock fragments. Geothermics, 30, pp. 93-110.

Trudgill, B., J. Cartwright 1994: Relay-ramp forms and normal-fault linkages, Canyonlands National Park, Utah. - Geological Society of America Bulletin, 106, pp. 1143-1157.

Vosteen, H., R. Schellschmidt 2003: Influence of temperature on the thermal conductivity and thermal diffusivity for different types of rock. - Physics and Chemistry of the Earth, 28, pp. 499-509.

Zampieri D. 1995: Tertiary extension in the southern Trento Platform, Southern Alps, Italy. - Tectonics, 14, pp. 645-657.

Zampieri D., P. Fabbri, M. Pola 2009: Structural constraints to the Euganean Geothermal Field (NE Italy). - Rendiconti online della Soc. Geol. It., 5, pp. 238-240.

Zampieri D., M. Pola, P. Fabbri 2010: The fissure ridge of Abano Terme (Padova). - Rendiconti online della Soc. Geol. It., 11, pp. 364-365 